http://journals.ums.ac.id/index.php/ijolae

\title{
Critical Review: Professional Development Programs to Face Open Educational Resou- rces in Indonesia
}

\author{
Rian Fitriansyah ${ }^{1}$, Lisfatul Fatinah ${ }^{2}$, Muhammad Syahril ${ }^{3}$ \\ ${ }^{1}$ Faculty of Education, the University of Hong Kong, Hong Kong \\ ${ }^{2}$ London School Centre for Autism Awareness, London School of Public Relations, Indonesia \\ ${ }^{3}$ College of Art and Social Sciences, Australian National University, Australia
}

DOI: 10.23917/ijolae.v2i2.9662

Received: December $26^{\text {th }}, 2019$. Revised: January $30^{\text {th }}, 2020$. Accepted: February $4^{\text {th }}, 2020$

Available Online: February $8^{\text {th }}, 2020$. Published Regularly: July $1^{\text {st }}, 2020$

\begin{abstract}
Information and Communication Technology (ICT) in education has become an important issue in education reform in many countries such as Hong Kong, Singapore, the United States, and the United Kingdom. Education reform is needed to give skill set of the 21 st century to students. Indonesian government has begun implementing ICT in education since 2002 marked by the establishment of the Indonesian Telematics Coordinating Team (TKTI). Although the development of ICT is still far away compared to Hong Kong and Singapore, ICT development is on the right track. In 2013, Indonesia began to initiate Open Educational Resources (OER) and teacher training on ICT. Open educational resources are digitized materials that can be freely accessed by those who want to teach, learn, or research. The OER initiatives have many challenges ahead, one of them is the development of the OER community involving all teachers in Indonesia. The gap in education quality between islands in Indonesia is added with the differences of education infrastructure and education resources. Therefore, Indonesia must create personalized professional development program based on the need of each island. The Indonesia government could initiate the OER consortium to unite all teachers to build a knowledge society. The methods of creating a professional development program could be deducted from the U.S. which has many districts and gap in education quality between states. The purpose of this paper is to develop a professional development program in creating the OER community in Indonesia. This paper tries to investigate what kind of professional development that has been set in, analyze the problems that would likely to occur, and give some solutions.
\end{abstract}

Keywords: professional development, open educational resources, teacher training, OER Corresponding Author: Rian Fitriansyah, Faculty of Education, the University of Hong Kong, Hong Kong Email:rian@connect.hku.hk

\section{Introduction}

Indonesia is a country with 35 provinces where each province has its local government policy, tradition, and culture that indicate its uniqueness (Indonesia Education Statistics [IES], 2017). As well as their education system, some provinces have implemented ICT in their schools and use IT suite to support their learning process, but some provinces don't implement ICT at all and still using a whiteboard as a tool for their teaching method (Hermawan, Yunita, \& Deswila, 2018). This shows that Indonesia's education quality might differ and have some gaps in some provinces. The gaps indicate that there is a need for education reform in Indonesia. This paper focuses on reviewing the professional development program for ICT implementation especially in open educational resources.

ICT was established by the Indonesian Telematics Coordinating Team (TKTI) in 
2000 (Farrel \& Wachholz, 2003). They began implementing ICT in 5 years action plan which also addressed ICT in education as one of its many issues. Education was one of four sectors to prioritize. It was designed as a collaborative project between ICT industry and ICT educational institutions, ICT will be learned through curriculum, ICT as learning tools in schools, universities and training centers, and establishment of distance learning with the use of Internet (UNESCO, 2003). Unfortunately, all those action plans did not go and complete as they were planned.

Besides, to help improve the education quality especially for students' and teachers' learning, Indonesia began to initiate open educational resources in 2013. One of its products is http://belajar.kemdikbud.go.id (UNESCO, 2013). This platform is used to provide learning resources for both student and teacher and learning management system for the teacher to teach them the new curriculum reform (UNESCO, 2013).

In reviewing, the professional development program (PDP) for the teacher in Indonesia, it will be compared the PDP for the teacher in the United States of America (US) and Indonesia because they have similar conditions in their states/provinces. US has been implemented ICT in their education since 1996 (Roumell \& Salajan, 2013) 8 years earlier than Indonesia. In terms of technology readiness, the US has achieved a lot of progress in researching how the technology works in education (United States Office of Educational Technology, 2017) that Indonesia could learn from the US.

This paper is divided into four parts. The first part is the introduction consists of Indonesia's education background, the brief history of Indonesia ICT implementation, the initiation of Indonesia OER and the teacher's training, and some brief explanations of the
US professional development framework. The second part is literature reviews of ICT in education, teachers' professional development program (PDP) in ICT, U.S. professional development framework, community of practice, Indonesia education statistics, and Indonesian teachers' professional development program, and Indonesia OER. Then, the third part is the discussion and reviews of the Indonesia education statistics, this paper will review the teacher's competency and ICT implementation in each school level. This paper will then analyze the problem in the implementation of PDP and OER. All the problems will be themed to see if there is a similar problem in any area. This paper will also try to see if there is any community of practice $(\mathrm{CoP})$ that has been created after PDP finishes. Suggestions to the next Indonesia PDP based on the review by adopting U.S. professional development framework and implementing CoP for the OER community will be given afterwards. Finally, the last part is the summary and conclusion of the paper.

\section{Literature Review}

In this section, this paper will provide all the literature review that supports the case review study including ICT in Education, Professional Development Program for ICT Implementation, U.S. Professional Development Framework, Community of Practice, Indonesia Education Statistics, Indonesian Professional Development Program for ICT Implementation and Indonesia Open Educational Resources.

\section{a. ICT in Education}

ICT in education is one of many important issues in education reform in many countries in Asia (Cheng, 2017; Hermawan, Yunita \& Deswila, 2018), the US (USOET, 2017) and the UK (Condrads et al., 2017). ICT implementation is important to acquire 
21st-century skills especially in digital skills (Odewumi, 2019; Law et al., 2016) because the traditional concept of learning is changing from teacher-centered learning to student-centered learning. To implement ICT in education, a country must create Information Technology in Education (ITEd) policies to be its guideline or pathway.

\section{b. Teacher's Profesional Development Proram in ICT}

Darling-Hammond, Hyler \& Gardner (2017) define teachers' PDP in ICT as a program to support teachers in teaching the students for 21st-century skills. Teachers' PDP in ICT is essential nowadays, the world is growing rapidly and so does the technology, if the teacher lacks competency in digital skills then they may not compete with another teacher who is tech-savvy or might not know what the students' needs in this era. Many nations mentioned that teachers should participate in the PDP to educate them in implementing ICT in education (Cheng, 2017; USOET, 2017; Roumell \& Salajan, 2016; Conrads et al., 2017). This indicates that PDP is important for education reform.

\section{c. U.S. Teacher's Profesional Develop- ment Framework}

Desimone and Garet (2015) have suggested best practices in U.S. teacher's professional development framework that consists of five key features, there are content focus, active learning, coherence, sustained duration, and collective participation. While Darling-Hammond, Hyler \& Gardner (2017) suggest three more features namely using models of effective practice, providing coaching and expert support, and offering feedback and reflection. This paper use the combined key features because they are inseparable and completing each other.

Content focus is related to the activities which focus on learning material and how to learn from it (Desimone \& Garet, 2015). Active learning is activities that are more focused on student-centered learning like discussion, group project, reflection and so on (Desimone \& Garet, 2015). Coherence means that the learning material, objectives and activities still align with the school curriculum, teachers' knowledge, students' needs and government policies (Desimone \& Garet, 2015). Sustained duration means the duration of professional development is still within 20 hours or more (Desimone \& Garet, 2015). Collective participation means there is a community of practice built after the professional development program (Desimone \& Garet, 2015). Using models of effective practice means that the teachers will be provided with the best practice in teaching with ICT (Darling-Hammond, Hyler \& Gardner, 2017). Coaching and expert support means some experts in the field are recruited to support the teachers' needs (LIP, 2017). Then, offering feedback and reflection helps facilitate teachers in their learning process (LIP, 2017).

\section{d. Indonesia Teacher's Professional De- velopment in ICT}

Indonesia has developed teachers' professional development in ICT since 2000 (UNESCO, 2013). There were no exact numbers of how many teachers were already or being trained but the focus on the training is still on how to use ICT not how to teach with ICT (UNESCO, 2013). Report in 2004 (UNESCO, 2013) informed that Pustekkom (The center of ICT for Education in Indonesia) focused on training teacher in how to integrate ICT into curriculum and pedagogical practices to develop 21 st-century skills. It was reported that the ministry of education had been developing an ICT competency for the teacher as shown in figure 1 below. Because it is now still under development, we 
still do not know how many teachers in In- standard. donesia are qualified with ICT competency

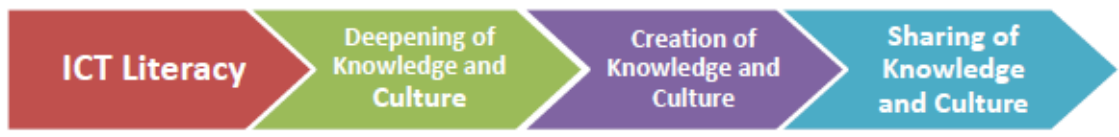

\begin{tabular}{|c|c|}
\hline Policy & \\
\hline $\begin{array}{c}\text { Curriculum \& } \\
\text { Assessment }\end{array}$ & \\
\hline Pedagogy & \\
\hline ICT & \\
\hline $\begin{array}{c}\text { Organisation \& } \\
\text { Administration }\end{array}$ \\
\hline $\begin{array}{c}\text { Professional } \\
\text { Development }\end{array}$ \\
\hline
\end{tabular}

Figure 1. Teacher ICT Competency Standard in Indonesia (UNESCO, 2013)

\section{e. Community of Practise}

Wenger (1998) defines the community of practice $(\mathrm{CoP})$ as a form of participation and people have different experiences in taking part in it. It has different stages of development based on their interaction and activities. It is one example in the learning of $21 \mathrm{st}$ century skills (Prestidge \& Main, 2018) for collaboration to help build knowledge society especially for teachers' learning. In Indonesia there are some examples of community of practice for teachers, the first one is which was developed by one of the private schools in Indonesia, and Ikatan Guru Indonesia (Indonesian Teachers Association) which was initiated by Ahmad Rizali in 2000.

\section{f. Open Educational Resources}

Open educational resources (OER) is a movement in building a platform to share each other's educational content (Caswell, Henson, Jensen, \& Wiley, 2008). Its purpose solely to provide digital learning material for everyone, so they could learn high-quality material for free (Caswell et al., 2008). Indonesia initiated OER in 2013 and 2017 via the establishment of Rumah Belajar and Indonesia Open Educational Resources (I-OER) (2019).

\section{g. Indonesia Education Statistics}

The paper will show the education statistics from the Ministry of Education in Indonesia in 2017/2018, unfortunately, the recent education data in 2018/2019 has not been released in public. This will be explained deeply in the third part and focused on represents the data that is aligned with PDP and OER implementation. The data consist of teachers' qualification, percentage of students in each level and school infrastructure implementation.

\section{Method}

The paper uses integrative and extensive literature review. It includes reviewing, examining, and synthesizing representative literarure and the main ideas on the related 
issues. The review is organized thematically or using conceptual categories around the topics rather than the progression of time. Four phases are used to review and assess the quality of the literatures. They are designing, conducting, abstracting and analysing data, and structuring and writing the review phase. The data is analysed in relation on the overall research and questions and the data abstracted. All the analysis process is described transparently. The result of the review is reported clearly, and the questions and directions for the further research are included.

Descriptive qualitative method in analysis is applied. The data used was mostly from Indonesian reports before the UNESCO, which were used to present Indonesia education in the UNESCO forum.

\section{Result and Discussion}

In this part, the paper discusses thoroughly how to create PDP that is suitable to face OER. First, there will be a deep review in Indonesia education statistics consists of the teachers' competency level in Indonesia and ICT implementation in Indonesia. Then, there will be a thorough review of Indonesia teachers' professional development in ICT. A thorough review of Indonesia OER will follow afterwards and finally a discussion in how the Indonesian government implements PDP based on U.S. PDP framework.

\section{a. Thorough Review of Indonesia Edu- cation Statistics}

Here are the lists of Indonesia education statistics, the first on is the students' graduate-level in Indonesia. Figure 2 shows the teachers' qualifications in 2009, and figure 3 shows the teachers' qualifications on every education level in 2017. It can be seen in figure 2 that the highest qualification of teachers is Ph.D., but only 60 teachers that are qualified with that degree. The lowest degree is below D1 (Extension level before the bachelor's degree) or in number they are 722.293 teachers. Furthermore, most of the teachers have bachelor's degree. They are 1.032.349 teachers.

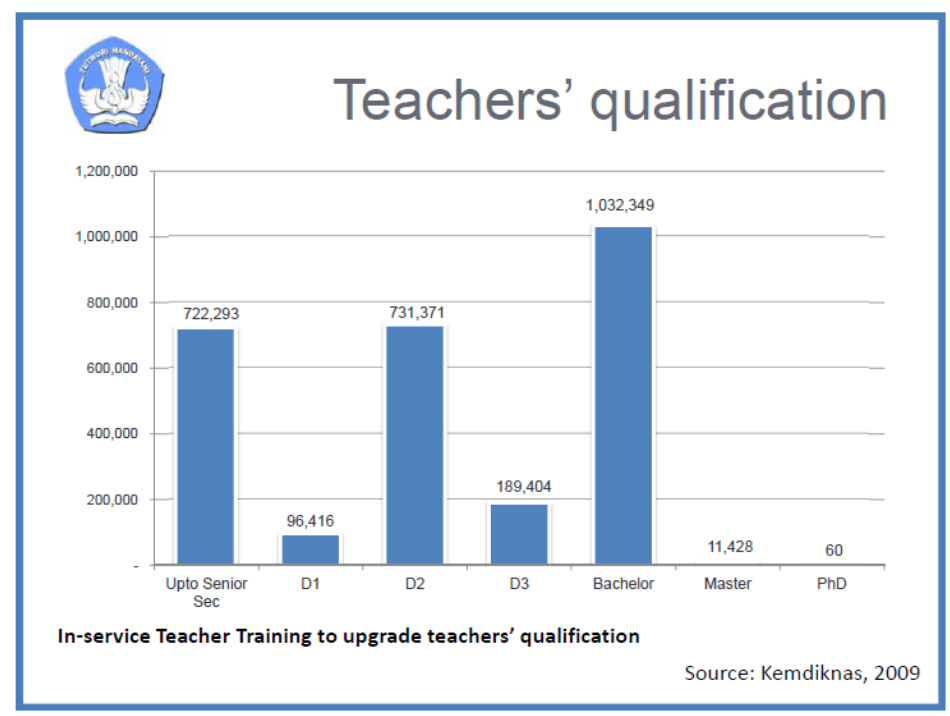

Figure 2. Teachers' Qualification (UNESCO, 2013)

Meanwhile, in figure 3 it can be seen that most of the teachers are qualified within a bachelors' degree (red bar) than below bachelors' degree (green bar) which shows that there is a significant difference between 2009 and 2017 in teachers' qualification. 
This is a very good reform in teacher's qualification.

On the other hand, Indonesia educational system has Teacher Competency Test (TCT) that quantifies teacher competency which is online based test since 2012. Based on Ministry of Education and Culture data, in 2012 the highest score of TCT is 47.84/100 whereas the minimum standard of the test is 70/100. In 2019, despite the minimum stan- dard is still $70 / 100$, the highest score of TCT is $69.12 / 100$. Teachers who could not reach the passing grade were not teachers with a lack of knowledge or experience in teaching. They failed simply because of their low basic ICT skill level. They did not know how to use a mouse and keyboard, how to open the examination application, and how to answer the online examination (Yusri, Iin Karmila et.al, 2013).

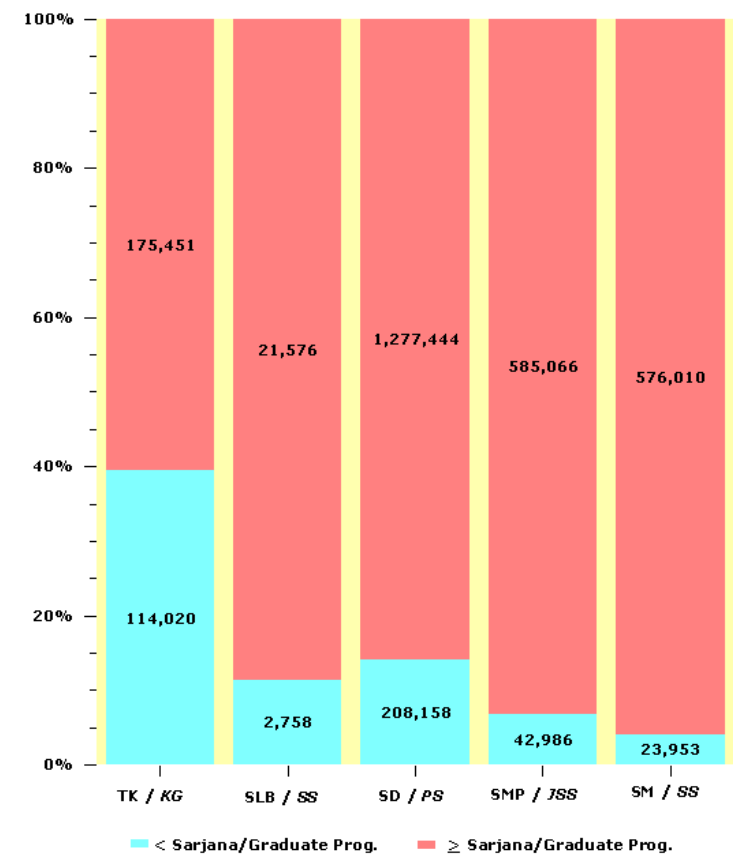

Figure 3. Percentage of Number of Teacher by Highest Certificate and Level of Education (IES, 2017)

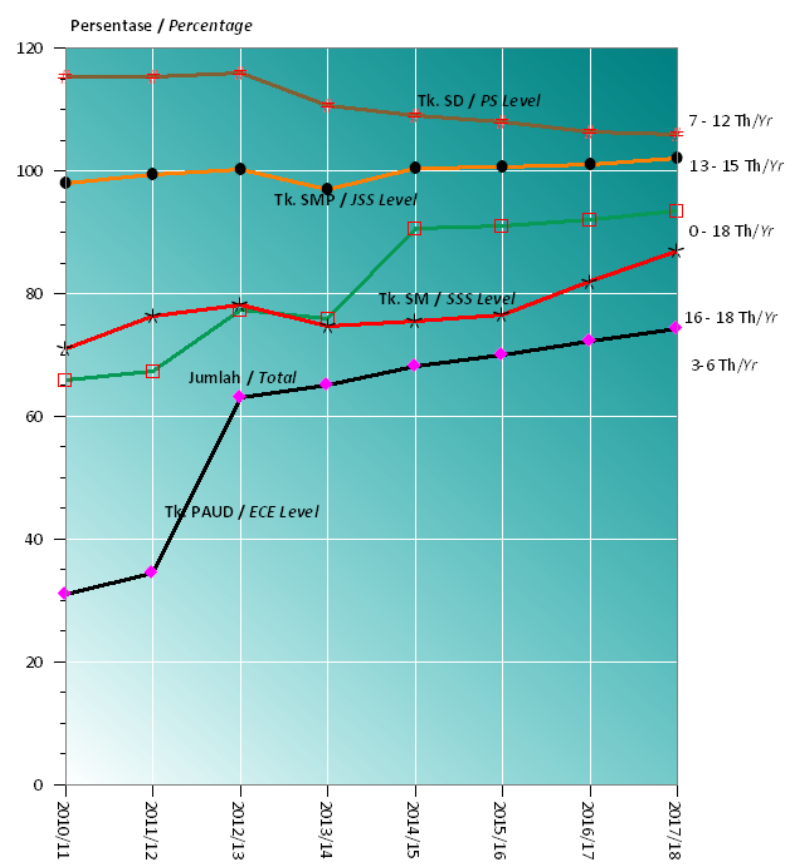

Figure 4. Trend Percentage of Pupils to School-Age Population 2010/2011-2017/2018 (IES, 2017) 
Afterward, to implement ICT in education, the infrastructure must be ready to serve the ICT. Figure 5 shows the ratio and projection PCs needed by schools in 2010-2025 from the 2009 report. The data shows that the total number of an ideal of PCs is 3.650.640. In 2020 for elementary schools, each school should have 40 PCs, for junior high school, each school should have 60
PCs, for senior high schools, each school should have 108 PCs and for university level, each university should have 240 PCs. It is still not clear whether this was implemented successfully or not because there no follow-ups report found in the UNESCO database or within the Ministry of Education in Indonesia database.

Table 1. PCs Projection and Ratio Needed by Schools 2010-2015 (UNESCO, 2013)

\begin{tabular}{|c|c|c|c|c|c|c|c|}
\hline \multirow[t]{2}{*}{ No. } & \multirow[t]{2}{*}{ Level } & \multirow[t]{2}{*}{$\begin{array}{l}\text { Number } \\
\text { of School }\end{array}$} & \multirow[t]{2}{*}{$\begin{array}{l}\Sigma \text { Ideal of } \\
\text { PCs }\end{array}$} & \multicolumn{4}{|c|}{$\begin{array}{c}\text { Ratio } \\
1 \text { School : } \Sigma \text { Komputer }\end{array}$} \\
\hline & & & & 2010 & 2015 & 2020 & 2025 \\
\hline 1. & SD & 144.228 & 1.442 .280 & $1: 10$ & $1: 20$ & $1: 40$ & $1: 60$ \\
\hline 2. & SMP & 28.777 & 5.75 .540 & $1: 20$ & $1: 40$ & $1: 60$ & $1: 80$ \\
\hline 3. & SMA & 10.762 & 387.432 & $1: 36$ & $1: 72$ & $1: 108$ & $1: 144$ \\
\hline 4. & SMK & 7.592 & 273.312 & $1: 36$ & $1: 72$ & $1: 108$ & $1: 144$ \\
\hline 5. & SLB & 1.686 & 8.430 & $1: 3$ & $1: 9$ & $1: 15$ & $1: 20$ \\
\hline 6. & MI & 21.529 & 215.290 & $1: 10$ & $1: 20$ & $1: 40$ & $1: 60$ \\
\hline 7. & MTs & 13.292 & 265.840 & $1: 20$ & $1: 40$ & $1: 60$ & $1: 80$ \\
\hline 8. & MA & 5.648 & 203.328 & $1: 36$ & $1: 72$ & $1: 108$ & $1: 144$ \\
\hline \multirow[t]{2}{*}{9.} & PT & 3.532 & 282.560 & $1: 80$ & $1: 160$ & $1: 240$ & $1: 320$ \\
\hline & $\begin{array}{l}\text { Total } \\
\text { Number }\end{array}$ & 237.046 & 3.650 .640 & & & & \\
\hline
\end{tabular}

Notes:

- SD: Elementary School

- SMP: Junior High School

- SMA: Senior High School

- SMK: Vocational High School

- SLB: Special Education School

For the rural area the ICT was implemented with 14 learning resources center utilized by solar panel, parabolic dish and LAN (UNESCO, 2013). Unfortunately, there is no progress report for ICT implementation in both school levels or rural area within ministry of education in Indonesia database or the UNESCO database. To develop PDP in OER it is strongly suggested that the infrastructure should be ready for used, because
- $\quad$ MI: Islamic Elementary School

- MTs: Islamic Junior High School

- MA: Islamic Senior Hight School

- PT: Diploma/ University

it needs strong Internet connectivity and some hardware specifications.

\section{b. Deep Review of Indonesia Teacher's Profesional Development in ICT}

Based on the Farrel \& Wachholz report (2003), there are several attempts for teachers' PDP in ICT, one of them is the collaboration of Pustekkom and the Directorate General of Pri- 
mary and Secondary Education (DGPSE) which trained some 800 high school teachers for computer-assisted learning. The groups of teachers were trained in using ICT, create digital learning materials and tools for their own pedagogical practices (Farrel \& Wachholz, 2003, 2003). The purpose of this PDP is the teachers will be able to provide their own learning instruction tools, but the objectives have not been met yet because they still using tools provided by Pustekkom rather than creating one for themselves (Farrel \& Wachholz, 2003). There is also a basic computer training provided by APEC Cyber Education Network (ACEN) in 2001 and continued by National Office for Educational Research and Development (Balitbang) for implementing the e-learning platform in 2002 (Farrel \& Wachholz, 2003).

We see that there is a lot of training that has been provided but unfortunately, not all the PDP meet the expected results. There are due to multiple factors, first is limited teachers' participations due to training location, time, and opportunity (Yusri, Iin Karmila et. al, 2013), second is a lack of motivation as mediation toward teachers' readiness to apply ICT in teaching and learning (Compriady, 2015). This second problem affects teachers' knowledge, skills, and usage of ICT. Third is teachers are lack of design thinking and disposition, forth is no strategic plan in implementing ICT in education nor a teachers' competency standards in ICT, fifth is the government at that time focuses on basic welfare and political stabilization because of mid-crisis in 1997, the last one is the learning content for using ICT is limited in Indonesian language (Farrel \& Wachholz, 2003).

For the first problem, it is suggested that the government provide PDP in ICT in many types, not only face to face PDP, in-house training, web based, and blended PDP but the mobile learning for ICT training as well. This is to remove geographical challenge, cost, and time problem so that teachers' participation can be increased. For the second problem, there is a need to develop a positive attitude toward ICT in education. Copriyady (2015) suggests that the government provi- des facilities to train teachers and advocate for technology's advantage to the teachers and students alike. For the third problem, it is suggested that teachers develop technological pedagogical content knowledge (TPACK) to resolve technology integration issues related to ICT. The forth problem, it is suggested that the Indonesian government continues to develop ITEd policies and teacher's competency standards in ICT, those policies will be the guideline for all schools in Indonesia to create their own teachers' PDP or by governments' initiative. For the second problem, it is suggested that if to have a total reform in education then the education must be a priority for the nation's development, consider the education's reform is align with sustainable growth of nation's economy (Salas-Pilco \& Law, 2018). And for the last problem, it is suggested that there should be a budget to translate the learning content into Indonesian mother's language because not all the teachers have the competence to understand English.

\section{c. Deep Review of Indonesia Open Edu- cational Resources}

Based on the literature review, Indonesia has developed an open educational resource via Rumah Belajar and I-OER. In Rumah Belajar, there are a total of 779.365 users divided by 224.394 teachers and 554.971 students (Ministry of Education in Indonesia, 2019). Based on the UNESCO report (2013), there were 3.7 million teachers and 51.3 million students in Indonesia, in other words, the platform has just been used by $1 \%$ of the total of teachers and students.

Another platform is I-OER developed by the University of Indonesia. In the website, it is said that it has acquired 50 universities to collaboratively develop the website's content (I-OER, 2019). Then, based on the UNESCO report (2013) there are 3.696 higher education institutions in Indonesia, so the website acquisition is still $1 \%$ of the total universities. It is very sad to see how the platforms are still not acquiring a lot of users even though the material is free and could be accessed anywhere and anytime.

Comparing the government-made OER with the private-made OER, there is no discrepancy of 
content quality between them. One of the private-made OER in Indonesia are SUAKA-UT made by Open University (Universitas Terbuka). They made the OER within 4 scoops which are faculty of science, faculty of social science and political science, faculty of education and graduate program. They have made an OER within K1 to K12 education level in different website. Unfortunately, there is no data on how many users are in those websites. But this movement made by UT were very promising and a great start to support the OER movement.

It is now understood that the open educational resources are still not used by many students and teachers. The Indonesian government needs to focus on acquiring a lot of users by digital advertising or collaborating with a lot of schools or higher education institutions. For digital advertising, the government could use TV ads or attach their ads in social media platforms, or they could attach it too in Google ads. Moreover, creating ads in digital world is cheaper than in conventional way.

Discussions Indonesia Teacher's PDP in OER based on U.S. Profesional Development Framework

Indonesia teachers' ICT competency standards are still in development although the draft of the policy exquisite in the first look. It covers most of the areas for ICT development including policy, curriculum \& assessment, pedagogy, ICT, organization \& administration, and professional development. Their knowledge is based on their digital literacy skills which is one of the 21 stcentury skills.

Furthermore, OER is still in development until now, so PDP regarding OER is still relevant. It is suggested that the PDP should investigate eight key features from U.S. Professional Development Framework which are the content focus, active learning, coherence sustained duration, collective participation, uses models of effective, coaching and expert support then offers feedback and reflection.

The training should focus on just using OER as a learning tool, the training should define which OER that will be used to demonstrate the training is it http://belajar.kemdikbud.go.id or http://i-oer.cs.ui.ac.id/ or maybe another OER collaborate with third-party institutions. Then, the training should be active learning or so we called student-centered learning, the teachers must have a group project like developing content materials together or maybe discussing their own experience with other teachers, so they don't need to passively listen to the instructor. Another one is the training' learning material should be coherence to the recent curriculum and follow the guideline of ITEd policies. The training shouldn't be too short or long, it may be two days in a row. The training should provide coach and expert that is expertise in the OER field so they could have direct feedback from the coaches. The coaches will be responsible for 5 teachers, for example, cater to the teachers' individual needs. And finally, post-training there should be a development of a community of practice in a form of Facebook group or Whatsapp group so everybody could follow up their training result and learn again from each other's teaching in the future.

There is no need to implement personalized professional development program in each province since any factors related to education differences in every province to develop an effective PDP in the US is not found. If there is any area that hasn't implemented ICT in their education then the government should focus on building the infrastructure first, after that they could start to teach the teachers how to integrate ICT in their learning process. This could be seen by thorough research which area is still vulnerable in implementing ICT in education.

\section{Conclusion}

In conclusion, Indonesia is still developing the ICT in education in its nation especially in OER Indonesia still has a lot of homework regarding infrastructure, the acquisition of the OER platform, and the readiness of teachers' ICT competency. It is suggested that some teachers' PDP in OER based on the U.S. professional development framework that may be beneficial in the 
future PDP like the content focus, the training must be active learning, coherence and should be done within 2 days. Furthermore, there should be coaches and experts to provide direct feedback and in the post-training, there should be a creation of a community of practice to follow-up each other's teaching in the future. Each province has their own education priorities, the government should know if the province is ready to be taught how to integrate ICT in their education or not. If it is ready then the government should focus on enhancing teachers' quality with PDP, if it's not ready then the government should focus on building the infrastructure for ICT implementation first.

\section{References}

Caswell, T., Henson, S., Jensen, M., \& Wiley, D. (2008). Open Educational Resources: Enabling Universal Education. International Review of Research in Open and Distance Learning, 9(1).

Cheng, K. M. (2017). Advancing 21st century competencies in East Asian education systems. Center for Global Education. Asia Society, 2.

Conrads, J., Rasmussen, M., Winters, N., Geniet, A., \& Langer, L. (2017). Digital Education Policies in Europe and Beyond: Key Design Principles for More Effective Policies. Luxembourg: Publications Office of the Europeasn Union.

Copriady, J. (2015). Self-motivation as a mediator for teachers' readiness in applying ICT in teaching and learning. Procedia-Social and Behavioral Sciences, 176, 699-708.

Darling-Hammond, L., Hyler, M. E., \& Gardner, M. (2017). Effective teacher professional development.

Farrel, G., \& Wachholz, C. (Eds.). (2003). Meta-survey on the Use of Technologies in Education in Asia and the Pacific. UNESCO Asia and Pacific Regional Bureau for Education.
Hylén, J. (2006). Open educational resources: Opportunities and challenges. Proceedings of Open Education, 4963.

Hermawan, H. D., Deswila, N., \& Yunita, D. N. (2018, July). Implementation of ICT in Education in Indonesia During 20042017. In 2018 International Symposium on Educational Technology (ISET) (pp. 108-112). IEEE.

Law, N., Lu, J., Wang, D., \& Lee, Y. (2016). e-Learning in formal, informal and open learning contexts: a study of global trends, policy options and their implications for sustainable development in Hong Kong. Hong Kong: CITE, University of Hong Kong.

Ministry of Education and Culture in Indonesia. (2019). Portal Rumah Belajar.

Ministry of Education and Culture in Indonesia. (2019). Neraca Pendidikan Daerah.

Odewumi, M. O., Falade, A. A., Adeniran, A. O., Akintola, D. A., Oputa, G. O., \& Ogunlowo, S. A. (2019). Acquiring Basic Chemistry Concepts through Virtual learning in Nigerian Senior Secondary Schools. Indonesian Journal on Learning and Advanced Education (IJO$L A E), 2(1), 56-67$.

South, J. (2017). Reimagining the role of technology in education. Retrieved from https://tech.ed.gov/files/2017/01/NETP1 7.pdf.

Prestridge, S., \& Main, K. (2018). Teachers as drivers of their professional learning through design teams, communities, and networks. Second handbook of information technology in primary and secondary education, 433-447.

Roumell Erichsen, E., \& Salajan, F. D. (2013). A comparative analysis of elearning policy formulation in the European Union and the United States: Discursive convergence and divergence. Comparative Education Review, 58(1), 135-165.

Salas-Pilco, S. Z., \& Law, N. W. (2018). ICT Curriculum Planning and Development: Policy and Implementation Lessons from Small Developing States. In ICT- 
Supported Innovations in Small Countries and Developing Regions (pp. 7798). Springer, Cham.

Snyder, Hannah. (2019). Literature Riview as A Reseach Methodology. Journal of Business Research 104 (2019) 333-339. https://doi.org/10.1016/j.jbusres.2019.07 .039

Tsai, Chin-Chung \& Chai, Ching-Sing. (2012). The "Third"-Order Barrier for Technology Integration Instruction: Implications for Teacher Education. Australasian Journal of Educational Technology 2012, 28(Special issue, 6), 1057-1060.

Toracco, Richard J. (2005) Writing Integrative Literature Reviews: Guidelines and and Examples.

United Nations Educational, Scientific and Cultural Organization. (2013). Indonesia: OER Initiatives \& ICT in Teachers' Training.
United States Office of Educational Technology (2017). Reimagining the role of technology in education. Retrieved from https://tech.ed.gov/files/2017/01/NETP1 7.pdf.

University of Alabama Libraries. How to Conduct Literature Review: What is a Literature Review? Retrieved from https://guides.lib.ua.edu/c.php?g=39963 $\& p=253697$

Wenger, E. (1998). Communities of practice: Learning as a social system. Systems Thinker, 9(5), 1-10.

Yusri, Iin Karmila \& Goodwin, Robert. (2013). Mobile Learning for ICT Training: Enhancing ICT Skills of Teachers in Indonesia. International Journal of eEducation, e-Business, e-Management and e-Learning, Vol. 3, No. 4, August 2013, DOI: 10.7763/IJEEEE.2013.V3. 243. 